Article

\title{
Achieving Sustainability: Insights from Biogas Ecosystems in India
}

\author{
Gita Surie \\ Department of Management, Robert B. Willumstad School of Business, Adelphi University, \\ Hagedorn Hall, Room 307A, One South Avenue, Garden City, NY 11530, USA; \\ surie@adelphi.edu; Tel.: +1-516-877-4625 or +1-609-947-2057
}

Academic Editor: Gbadebo Oladosu

Received: 11 August 2016; Accepted: 13 February 2017; Published: 21 February 2017

\begin{abstract}
This paper focuses on how the use of renewable energy technologies such as biogas can help to achieve environmental and socio-economic sustainability. It combines research on sustainable consumption and production, natural and industrial ecosystems and renewable energy adoption to develop a framework for an industrial ecosystem for biogas for bottom-of-the-pyramid and rural populations. The framework suggests that three dimensions of industrial ecosystems and a meta-dimension can be embedded in the design of a new industrial ecosystem for biogas to facilitate environmental and socio-economic sustainability. Case studies of an organization engaged in using biogas to create a sustainable bioenergy ecosystem for rural populations and two organizations producing biogas in urban India provide support for the framework.
\end{abstract}

Keywords: biogas; sustainable consumption and production models; designing ecosystems; India

\section{Introduction}

Technological change holds the promise of achieving Sustainable Development Goals [1] which envision a world that provides to all the opportunity to fulfil their aspirations and meeting the needs of the present without compromising the ability of future generations to meet their own needs [2]. Renewable energy technologies play an important role in addressing the challenge of achieving environmental sustainability [3]. In 2015, G7 and G20 committed to improving access to renewable energy and increasing energy efficiency, and the United Nations General Assembly adopted the Sustainable Development Goal for Sustainable Energy for All (SDG 7). In December 2015, 195 countries agreed to limit global warming to well below 2 degrees Celsius at the United National Framework Convention on Climate Change's 21st Conference of the Parties (COP21) in Paris as a part of this effort. The majority of countries committed to scaling up renewable energy and energy efficiencies through their Intended National Determined Contributions (INDCs). A total of 147 gigawatts (GW) of renewable power capacity was added in 2015, the largest annual increase ever, despite falling global prices and ongoing subsidies for fossil fuels, and other challenges to renewables [4], indicating that the push for renewable energy has gained momentum.

This paper focuses on the potential of bioenergy technologies such as biogas to address the goal of a sustainable and equitable future for all [1] in an emerging economy, India, where the challenge is to facilitate economic growth and meet the expected increase in demand for energy, while alleviating poverty, through the adoption of renewables such as biogas $[5,6]$. Commercializing new renewable energy technologies is challenging since they encounter the "valley of death" due to lack of attention paid to creating an industrial ecosystem [7-9] and forging new pathways to the market especially when technologies are disruptive [10]), leading to insufficient adoption. This paper combines key concepts such as the importance of interactions and linkages and diversity of organizational type for stability in natural and industrial ecosystems [7-9] with those from sustainable consumption and production, 
which emphasize consuming "green" products and services and using methods of production that minimize environmental impact [11-13] and with research on renewable energy adoption [14-16]. Based on these theories, a framework is developed using an ecosystems approach to stimulate biogas adoption, minimize environmental impact and achieve socio-economic sustainability. This paper examines the following research question: How can sustainable consumption and production be embedded into the creation of an industrial ecosystem for renewable energy (such as biogas) to minimize environmental impacts and ensure socio-economic viability and widespread adoption?

This paper applies the framework to biogas for bottom-of-the-pyramid (BOP) [17] populations in rural India that lack access to electricity and other basic amenities. Biogas from biomass such as cow manure or poultry litter at a small-scale is relevant because these inputs are locally available and do not require large infusions of capital. BOP markets also represent an important opportunity for innovations promoting sustainable energy production via technologies that target first-time users who may accept sustainable consumption and production (SCP) models more readily than established users where conventional technologies must be displaced. Case studies of an organization that successfully created a biogas ecosystem for rural populations in India and two organizations involved in producing biogas in urban India are presented to support the framework.

Bioenergy is important as it plays a role in all three sectors of energy use: heating (and cooling), electricity and transport. Solid biomass is the largest share of biomass used for generating heat and electricity while liquid biofuel is the largest source in the transport sector. The use of biomass for energy has grown at about $2 \%$ per year since 2010 , and the bioenergy share of total global primary energy consumption has remained at about 10\% since 2005 (see Figure 1 below). In industrialized countries, the focus is largely on liquid fuels such as biodiesel and ethanol (derived from biomass). In 2015, the United States, Brazil and Germany were leaders in biodiesel production, annual investment and net capacity additions while the United States, Brazil and China were the leaders in ethanol production [4]. However, in emerging economies, using land for food takes priority over growing biomass for energy. In recent years, research has focused on advanced biofuels derived from ligno-cellulosic materials [18], municipal solid waste, micro-algae and photosynthetic organisms [19]. However, these technologies are not yet commercially viable.

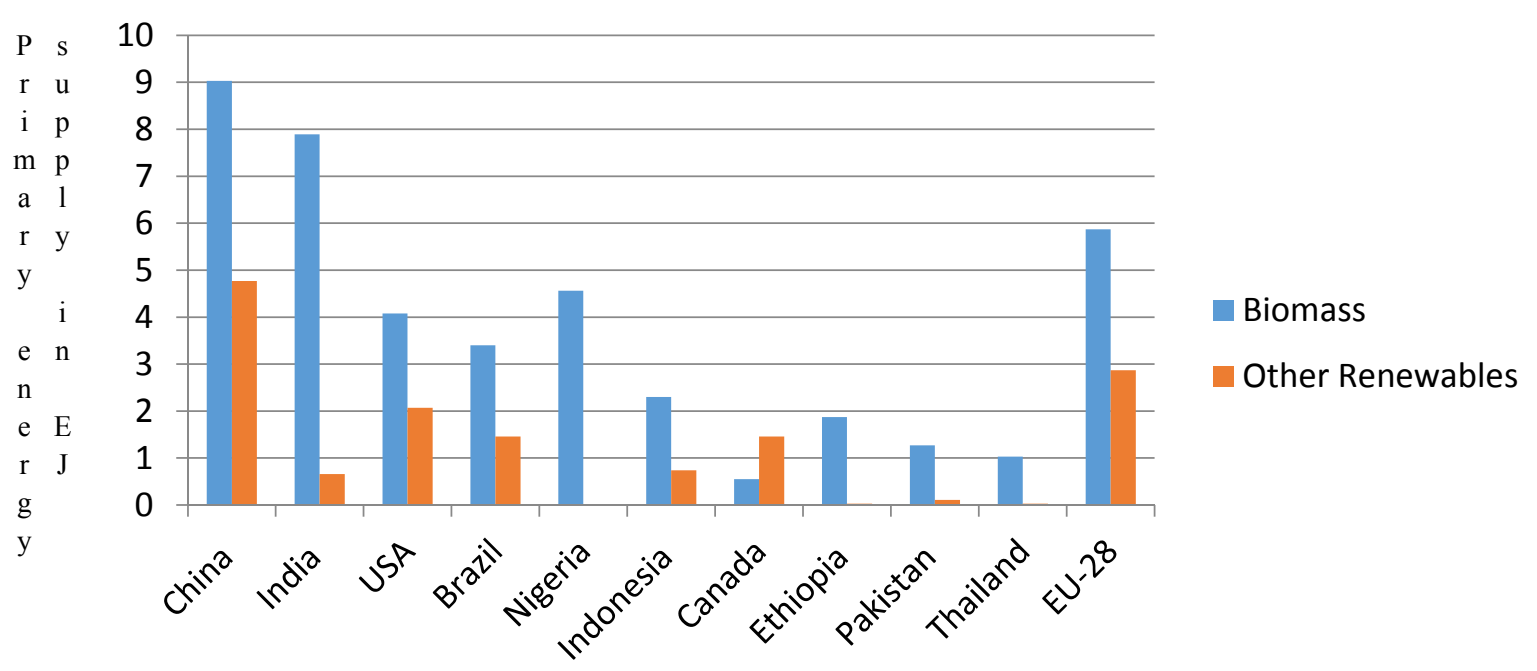

Figure 1. Energy supply from biomass and other renewables-2016 (Source: WBA Global Bioenergy Statistics 2016, World Bioenergy Association [20]). 
Hence, this paper focuses on biogas from organic waste, which is important for emerging economies since it can meet energy needs in rural areas where grid connectivity is poor or missing as well as in urban areas. Biogas is produced by anaerobic digestion of various types of organic matter including manure, agricultural residues, organic household waste and sewage. Capturing biogas from livestock eliminates methane release into the atmosphere. Methane is 25 times stronger than carbon dioxide as a greenhouse gas. Moreover, anaerobic digestion to produce biogas reduces odors and yields nutrient-rich liquid fertilizer [21].

The potential of biogas has been recognized in all economies. Global biogas production more than quadrupled from $0.28 \mathrm{EJ}$ to $1.28 \mathrm{EJ}$ from 2000 to 2013 with the highest increase in Asia. China, Germany and USA are the top three producers of biogas globally, while India ranks 9th [22]. A 4.4 megawatt (MW) project was launched in South Africa to produce electricity from cattle waste [4]. Tropical Power Kenya Limited installed a 2.8 MW grid-connected biogas plant in 2015 and plans to build plants producing more than $130 \mathrm{MW}$ across Africa by 2018 [23]. A 2011-2013 biogas audit conducted in Bangladesh suggests that though biogas technology has been widely adopted in Bangladesh and provides benefits such as clean fuel for cooking, problems exist such as insufficient feedstock and plants falling into disuse because of lack of maintenance and training [24]. In Asia, anaerobic digestion plants for waste materials have been deployed, mainly in Thailand and Indonesia. In Europe, the number of biogas plants rose by $18 \%$ from 14,569 in 2013 to 17,240 in 2014. Simultaneously, the total number of bio-methane plants increased 23\% to 367, with Germany, Sweden and U.K. leading in production [25]. In 2015, Macedonia installed a biogas plant for cattle waste of 3 MW capacity, and the European Bank for Reconstruction and Development agreed to finance a biogas plant in Ukraine.

This paper focuses on biogas from cattle manure in rural India because it offers decentralized solutions for rural populations. Chanakya et al. [19] note the importance of decentralized approaches due to the shortage of land for fuel crops in India and because it can mitigate greenhouse gas emissions. India's large population and rising energy needs from rapid economic growth (estimated at 7.9\% from April 2016 to March 2017 and 8\% in 2017-2018) make the adoption of renewables such as biogas imperative to alleviate pollution. India is an increasingly significant player in renewable energy; the government of India has allocated INR 34 billion (about USD 508 billion) for the bioenergy mission. Annual biomass availability in India, including agricultural, forestry and wasteland residues, is estimated at 915 million metric tons (MMT). The combined power potential is estimated at 33,292 MWe (megawatt energy equivalent). Together with power generation through bagasse cogeneration, the total estimated biomass power potential is above 40,000 MW [18].

Producing biogas from cattle manure is important for reducing forest degradation (forest biomass is used as fuel for cooking), one of the major contributors of greenhouse gas emissions in India [26]. India is the fourth largest emitter of greenhouse gases (GHGs) in the world [26]. About 89 percent of rural and 28 percent of urban households depend on firewood, chips and dung cakes for meeting energy needs [27]. Additionally, India has the largest cattle population in the world [28]. A national program on biogas since 1982 has seen over four million family sized biogas plants (2-4 $\mathrm{m}^{3}$ digester size) installed by 2010 [29]. Biogas can replace natural gas for powering gas engines to generate electricity and run motor vehicles. Slurry from digesters can be used as fertilizer [30]. Biogas has the potential to replace about 37 percent of fuelwood consumption and about 30 percent of the energy supplied by conventional fuels such as fuelwood, kerosene and LPG (liquefied petroleum gas) [31]. With 95 percent of livestock in rural areas, there is the potential to harness 48,220 million cum (cubic meters) of biogas per year and reduce GHG emissions by replacing fuelwood with manure management [31].

The next section outlines approaches to sustainability, natural and industrial ecosystems and renewable energy adoption and provides a framework for SCP. Section 3 outlines the methods and presents insights from organizations involved in creating biogas ecosystems for rural and urban India to support the framework. Section 4 provides a discussion and conclusion. 


\section{Approaches to Sustainability, Ecosystems, and Renewable Energy Adoption}

This section draws on three streams of literature relevant for the key themes discussed in this paper: sustainable consumption and production ( $\mathrm{SCP})$, natural and industrial ecosystem theory, and renewable energy adoption. SCP focuses on tools and techniques to modify activities in the production value chain and consumption life cycle of goods and services to reduce environmental impact. The literature on natural ecosystems and sustainability in industrial ecosystems provides insights on elements critical for stability in such systems. Likewise, the literature on renewable energy technology adoption sheds light on barriers. Together, insights from these streams of research helps build understanding of how to create an industrial ecosystem for biogas that facilitates adoption and is socio-economically and environmentally sustainable. While each research stream focuses on specific aspects of sustainability, insights from linkages between these independent streams have not previously been explored or leveraged.

\subsection{Sustainable Consumption and Production}

Sustainable industrial development can be facilitated through a "green economy" centered on "improved human well-being and social equity, while significantly reducing environmental risks and ecological scarcities" [32]. It involves changing consumption patterns to induce investment shifts towards green goods and services. The production side involves minimizing waste by using renewable resources as inputs and fuels and taking every possible precaution to avoid harming workers, communities, climate, or the environment [33-35].

The SCP concept was introduced at the Oslo symposium on Sustainable Consumption as "the use of goods and services that respond to basic needs and bring a better quality of life, while minimizing the use of natural resources, toxic materials and emissions of waste and pollutants over the life cycle, so as not to jeopardize the needs of future generations" (Norwegian Ministry of the Environment, 1994) [36]. It was further refined as "a more efficient use of resources in developing countries, which expands the resource base to meet human needs, and a change in the consumption patterns to achieve reduced overall material and energy use in developed countries" [36]. Sustainable production refers to improving products and production processes to reduce consumption of resources over the full life cycle of products or processes [36].

In September 2015, the United Nations announced the 2030 Agenda for Sustainable Development wherein 17 Sustainable Development Goals (SDGs) and 169 targets were outlined to transform the planet to address economic, social and environmental concerns. The Millenium Development Goals (the precursor to the SDGs) failed to achieve poverty eradication [37] attributed to over-consumption by the richest $20 \%$ of the world's population, which consumes over $80 \%$ of global output and is hard to regulate.

Paul Ehrlich and Holdren [38] noted that the impact on the biosphere (I) is the product of three variables: $I=P \times A \times T$-the dynamics of demography $(P)$, the degree of wealth or affluence $(A)$, and technology $(T)$, which indicates the amount of pollution per unit of GDP given a specific technology. As measures to control population are controversial and unpopular, policy makers and firms have focused on technology to alleviate pressure on ecosystems. While technology addresses production, affluence impacts consumption and demand of goods and services.

Sustainable production involves increasing resource productivity through cleaner technologies or managerial innovations to reduce environmental damage and improve firm competitiveness. Sustainable production strategies target innovation in process, product and systems [12]. Process innovation refers to technological or organizational solutions (at the level of the firm) that improve environmental performance by reducing pollution. Product innovation refers to changes in products or services that range from product improvement and redesign to radical changes in the product concept using tools such as Design for Environment (DfE) and Life Cycle Assessment to integrate sustainability into innovation [39]. System innovation refers to new organizational solutions at the system level rather than at the firm level, for example in the supply chain, in relations with suppliers, clients, 
competitors, government agencies and environmental groups. Solutions may be targeted to material handling to storage, sustainably managing natural resources (as in organic agriculture), developing eco-friendly products or managing the recovery and disposal of a product at the end of its life cycle (e.g., white goods and electronics). Sustainable production is measured as the degree of integration of environmental issues within the principles of business [12]. Krajnc and Glavič [40] provide indicators that reflect resource use, the product, environment, economic, quality and social aspects of sustainable production. While there has been progress, ironically, increased product efficiency has made possible increased consumption, creating a "rebound effect" [41]. Hence, it is imperative to focus on sustainable consumption in addition to sustainable production.

Sustainable consumption is defined as consuming differently, consuming efficiently, and having an improved quality of life [42]. Achieving sustainable consumption challenges the status quo. Consumer demand and behavior are influenced by non-economic factors such as sociological, psychological, technological and environmental issues and collective expectations shaped by cultural norms, values and attitudes [11]. Two strategies are possible: (1) shifting demand to low-impact consumption products; and (2) lowering material demand. Both involve all actors: governments, business and individuals [12]. The first strategy aims to encourage green shopping by modifying consumer attitudes towards environmentally friendly products and to boost demand for sustainable goods by educating consumers through eco-design and energy labelling. While businesses have committed to developing sustainable products and technologies, most consumers have not committed to adopting them. In fact, human consumption growth has been accompanied by natural resource depletion, an unsustainable increase in emissions, degradation or loss of forests [43] and, consequently, decline of vertebrate species populations by almost 50 percent from 1970-2015 [44]. The second strategy of lowering material demand through sustainable consumption requires a shift in behavior and consumption patterns to achieve environmental sustainability [13]. However, due to norms, habits and marketing, quality of life continues to be equated with material consumption [45]. Adopting an alternative model prioritizing freedom, security, social recognition, good health, concern for improving the environment, and a lifestyle consistent with these values is challenging. Additionally, it requires broadening the definition of wealth [46] to use new indicators such as Daly and Cobb's [47] 'Index of Sustainable Economic Welfare' and going beyond conventional measures such as GNP, GDP and employment for social well-being [13] as these do not address growing inequality, hidden costs and greater vulnerability to external shocks from economic growth and increasing globalization.

Energy efficiency presents an important opportunity for reducing consumers' energy use and emissions [13]. Moreover, in ecologically defensible societies, energy creation and energy sources would be decentralized and distributed with small groups and local communities in control of their own resources [48].

Finally, sustainable consumption can lead to self-actualization or self-realization. While the pursuit of material wealth or "artha" is recognized as a fundamental human motivation, it must be informed by "dharma" or the pursuit of righteous behavior if it is to lead to a mature self-understanding [49]. The mainstream approach to sustainable consumption is to focus on adapting consumption so that consumers buy "green products" [46]. Sections 2.2 and 2.3 highlight key features of natural and industrial ecosystems and factors affecting adoption of renewable energy and biogas. Section 2.4 draws on theories presented earlier and develops a framework for sustainable consumption and production to help integrate environmental and socio-economic sustainability in the design of new industrial ecosystems.

\subsection{Ecosystems}

\subsubsection{Natural Ecosystems}

Natural ecosystems are complex, adaptive systems characterized by historical dependency, non-linear dynamics, and multiple basins of attraction [50]. Outcomes from complex systems arise 
from the behavior of agents at a lower level of aggregation co-evolving with one another. Simple rules constrain behavior and can give rise to complex behavior [9,51]. A key theme in research on natural ecosystems is the idea of sustaining the system and maintaining resistance and resilience to change. Researchers have suggested that diversity of species in an ecosystem helps provide multiple services and contributes to resistance and resilience notwithstanding redundancy in function across species. [52,53].

Chapin et al. [53] indicate that an ecosystem is sustainable if key groups in the ecosystem maintain their characteristic diversity over the normal cycle of disturbances. Sustainability is influenced by climate, soil resources, major functional groups of organisms (functional groups are groups of species that have similar effects on ecosystem processes [53]), and a disturbance regime that both influences and is affected by ecosystem processes. Moreover, oscillations in these factors must remain within stable bounds for the ecosystem to be resistant and resilient to change. Negative feedback constrains changes in these factors. For example, negative feedbacks associated with food availability and predation often constrain changes in the population size of a species. Linkages among ecosystems in a landscape can contribute to sustainability by creating or extending the feedback network beyond a single patch. Likewise, changing the composition of species can affect ecosystem processes and sustainability.

Palumbi, Mcleod and Grunbaum [54] suggest that features of ecosystem stability-recovery, resistance, and reversibility-are features of overall resilience or robustness and advocate studying various species (for example, different species of trees or other organisms) and their interactions within the ecosystem. Holling $[55,56]$ defines ecosystem resilience as the amount of disturbance a system can absorb and still remain within the same state or domain of attraction. Resilience also encompasses the ability of an ecosystem subject to disturbance and change to self-organize, learn, adapt and renew itself [57]. Biological diversity is important in sustaining desirable ecosystem states and maintaining resilience [58], particularly the diversity of functional groups in a dynamic ecosystem and species diversity within these groups $[59,60]$. This is possibly because redundancy of species, processes and mechanisms within an ecosystem enables the maintenance of ecosystem services (for example, pollination services provided by bee populations [61]) due to the variability in responses of species within functional groups to environmental change.

Finally, research on the provision of ecosystem services emphasizes the importance of linkages and interactions in ecosystems. Various ecosystem services depend upon the movement of organisms and materials across landscapes and are influenced by landscape connectivity-the degree to which a landscape facilitates the movement of organisms and matter. Connectivity also influences biodiversity and ecosystem processes. Landscape composition and landscape configuration also affect the provision of ecosystem services such as pollination and pest regulation [52]. In natural ecosystems, species interact with other species directly and through abiotic factors in multiple ways, and, often form complex networks of interaction. Olff et al. [62] highlight various interactions including pollination, production of toxicants, exchange of organisms, materials and energy as well as predator-prey interactions that influence the distribution and abundance of organisms. Moreover, such interactions alter ecosystem dynamics through various interacting, mechanistic pathways, including species resource acquisition traits, population densities, ability to engineer changes to physical environmental conditions, effects on disturbance, the ability to structure habitat for other species, and their impact on food webs [63].

In summary, diversity of species and variety of interactions are key features of natural ecosystems that influence dynamics and help maintain stability. This can yield important insights for designing resilient industrial ecosystems.

\subsubsection{Industrial Ecosystems}

Viewing industry through an ecosystem lens is important because it focuses attention on the interactions of various organizations rather than on individual organizations and helps to understand how industries evolve. Industrial ecosystems are analogous to biological ecosystems in that each process and network of processes is viewed as a dependent and interrelated part of a larger whole [64]. 
Moreover, such systems need to be designed as many aspects of materials flows are defined by decisions taken very early in the design process [64].

Industrial ecosystems can be viewed as complex adaptive systems composed of subsystems at various levels; organizations are agents in the system. As noted above, the attributes of diversity and interaction are necessary for resistance (the capacity to withstand external shocks without loss of function) and resilience (the capacity to recover from disturbance) in natural ecosystems $[65,66]$. Iansiti and Richards [67] suggest that business ecosystem health is expressed via robustness, productivity and innovation (niche creation). Thus, sustainable industrial ecosystems are those that are socio-economically viable, preserve livelihoods, ensure reliability of energy supply and protect the safety of people, facilities, regions and the environment [68]. Like natural ecosystems, industrial ecosystems are "open" systems in that ecosystem processes receive some energy and materials from outside and use energy to transform and recycle materials internally and build ecosystem structure and then move some energy and materials back to the outside [65]. For example, Iansiti and Richards [67] note that in the information technology (IT) ecosystem, many organizations ranging from software application developers to venture capital firms influence the value of a single IT product. Other applications of an ecosystem approach include studies of Boston's industrial ecosystem viewed as a "manufactory of sectors" [7] and of knowledge and business ecosystems [8]. Smith [69] highlights that economies are also complex systems; increasing returns to scale are common and significant, increasing possible futures and decreasing the possibility of a long run optimum.

\subsection{Adoption of Renewables and Bioenergy}

Research on the adoption of bioenergy and other renewables indicates that the technological solutions to increase the availability of energy and water and reduce cost can be employed to overcome the limitations created by local resource availability. However, many renewable technologies are at an early stage of development, and their large scale adoption is influenced heavily by subsidies and other policies. Consumers' concern about the environment does not necessarily translate into heightened knowledge or willingness to pay more for renewable energy [14]. However, adoption of renewable energy policies is promoted by higher levels of knowledge, education [15,16] and income [16].

Modern bioenergy is a promising option to curb greenhouse gas emissions [70]. Moreover, organic agriculture can mitigate the negative environmental effects of conventional agriculture [71]. However, meeting global energy needs via biomass grown sustainably is problematic as burning biomass for fuel is likely to be incompatible with organic agriculture, which relies on biomass inputs for nutrient balance. In India, production of biofuel from Jatropha Curcas oilseeds was unsuccessful due to poor productivity of oilseeds, lack of promising varieties, rising wage rates and inefficient marketing channels, making its production economically unviable [18,72].

Other bioenergy sources include microalgae and their biomass, which can be developed into an alternative source of important feedstocks [73]. Yields of oil from algae are greater than from traditional oilseeds; additionally, they can be grown away from farmlands and forests, minimizing the damage caused to the environment. Third generation biofuels from microalgae address the drawback of first generation biofuels derived from terrestrial crops and second generation biofuels derived from lignocellulosic agriculture, forest residues and non-food crop feedstocks over competing land use and required land use changes [74]. Algal biofuel production in India is possible in flooded paddy crop land before the crop reaches dense canopies, in waste waters and salt affected lands without disruption of food security, water security and overall sustainability [19]. However adoption of these technologies requires ensuring socio-technical acceptance for reuse of wastelands, wastewaters and waste-derived energy and by-products [19]. New technologies for advanced biofuels from microalgae have been developed in the US, but are not yet commercially viable though companies have begun licensing their technologies for purposes such as water purification [18]. Despite its potential to mitigate greenhouse gas emissions, a key factor inhibiting the adoption of biogas is the lack of scale and high investment cost of many small biogas plants at an individual farm site [3]. To alleviate this problem, other energy 
crops can be used in combination to raise methane yields to permit increased plant size and, thus, lower the cost of producing biogas.

Other challenges to wider adoption of renewables include the lobbying effect of established industries in a set of European Union countries [75] and insufficient pressure to stimulate major developments. Overall, mass adoption of bioenergy technologies is impeded by lack of a "critical" level of concern for the environment as well as socio-technical constraints. Emerging economies like China and India have greater incentives to adopt renewables including biogas; however, many challenges such as diffusing knowledge and capabilities, and fostering entrepreneurship need to be addressed. The next section develops a framework for sustainable consumption and production.

\subsection{Framework for Sustainable Consumption and Production}

The emergence and development of biomass-based technologies helps integrate the concepts of sustainable consumption and production in designing new industrial ecosystems that are resilient and resistant to change, particularly for rural populations. The framework for such an industrial ecosystem is derived from theories discussed earlier. While the focus is on creating an industrial ecosystem for small-scale decentralized renewable energy technologies for rural populations (that are likely to adopt sustainable technologies to fulfil basic needs and do not have to re-model their behavior due to a prior history of mainstream consumption), these concepts can also apply to urban and semi-urban settings where creating an industrial ecosystem is necessary to facilitate adoption. Such community-oriented small-scale technologies provide a niche for new ideas, artefacts and practices to develop without full exposure to the range of processes channeling regime development [76,77]. If successful, these new alternatives become sufficiently robust to develop niche markets and attract mainstream interest [46,78].

Establishing an industrial ecosystem for biogas allows for incorporating sustainability from the perspective of reducing environmental impact and enhancing socio-economic viability. Key dimensions of such an ecosystem are outlined below.

First, given that complex systems evolve from simple rules that constrain behavior [66], establishing rules pertaining to sustainability for users and producers in the system can ensure this outcome. Thus, for example, when building the ecosystem, introducing simple rules such as "use only local resources as inputs", "use only renewable resources", "recycle waste" and "use local knowledge wherever possible" can help ensure that local resources such as biomass, manure and solar energy are used. Using local resources and knowledge lowers the cost of new technology adoption, thereby promoting sustainability and economic viability. Moreover, new biomass-based energy technologies are clean, replacing older technologies and methods that generate pollution in the home and the environment. The interaction of local agents constrained by these rules generates new behavior that can alter the system in the long term [66].

Second, diversity of species is necessary for resilient and robust natural ecosystems [65] and, analogously, in industrial ecosystems. Decentralized technologies that provide off-grid solutions such as biogas are viable for rural communities because they introduce new players in the industrial ecosystem by bringing the solution to the community, thereby changing its dynamics. The entry of new entrepreneurs, start-up organizations and social enterprises or non-governmental organizations increases diversity of organizational type and alters dynamics by focusing on a specific technology and forming a niche that may be ignored by existing players or of peripheral importance to them.

Third, using locally produced biogas rather than imported fuel reduces the cost of energy and helps the community become self-sustaining. As the technology is adopted and its economic viability established, additional opportunities for entrepreneurship (such as provision of inputs or services for maintenance of the technology or processing of waste) are pursued and new market niches discovered. Besides lowering cost and preserving local culture and traditions, using local, indigenous knowledge in the system may also lower cost and generate new market opportunities. 
Each of these three dimensions of the ecosystem acts to shape the others iteratively. Finally, as in natural ecosystems, interactions and linkages play an important role in maintaining resilience in industrial ecosystems and are considered a meta-dimension encompassing both the industrial ecosystem under consideration as well as other industrial ecosystems. Entry of new entrepreneurs and social enterprises generates new interactions with villagers in the context of new services and new ways to generate livelihoods. It also introduces linkages with other ecosystems via interactions with those outside the community bringing new resources, knowledge and capabilities [72].

In this way, alternative systems of provision that favor SCP can be generated in local contexts [46]. When such innovations are scaled up and become dominant, they have the potential to alter production-consumption systems and, consequently, the socio-technical regime itself [46], see Figure 2 below.

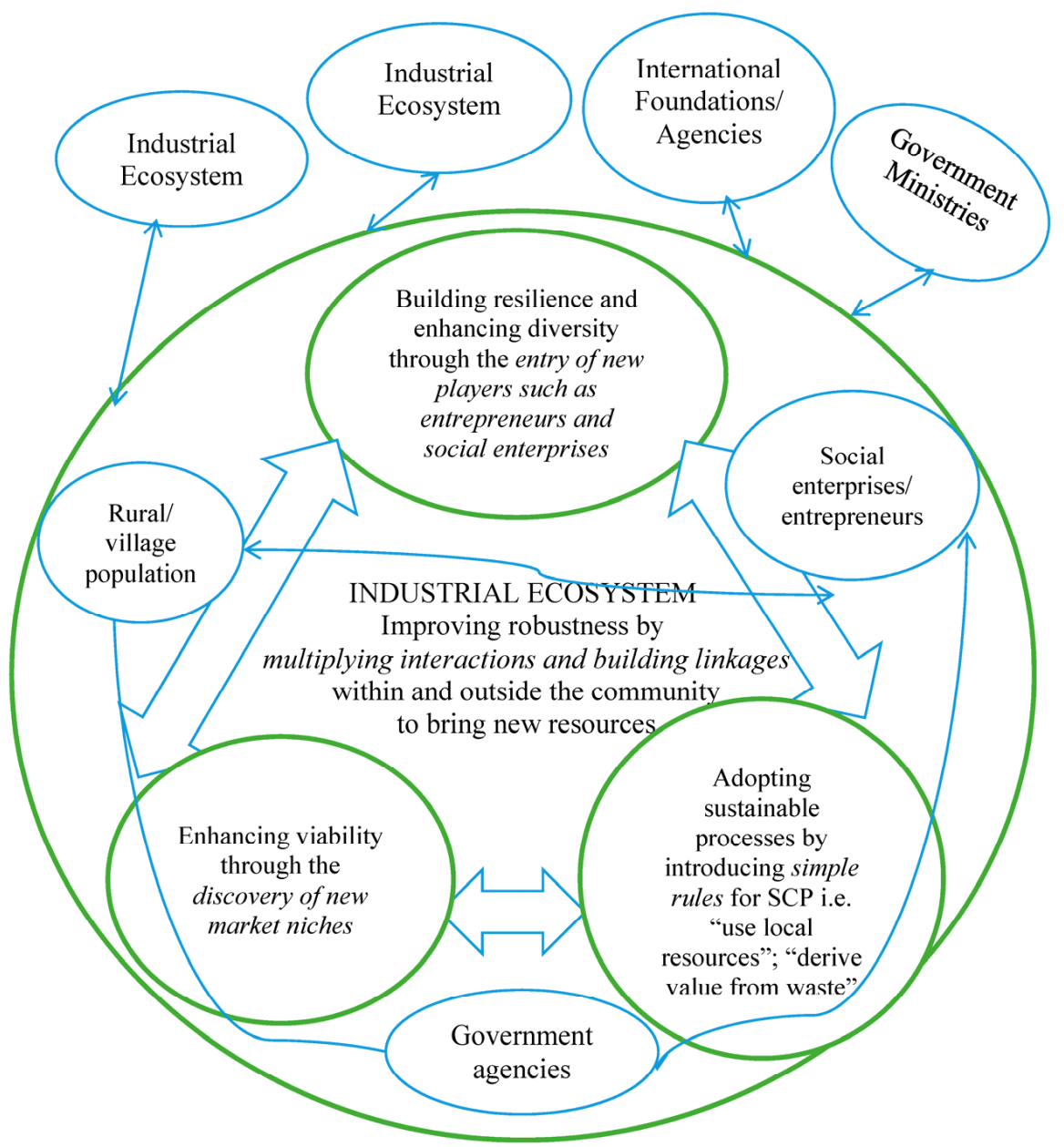

Figure 2. Dimensions of industrial ecosystem design for environmental and socio-economic sustainability.

Table 1 below summarizes the key themes in past research on sustainable consumption and production, natural and industrial ecosystems, and adoption of renewables and highlights the research contributions of this paper. 
Table 1. Integrating concepts from SCP, natural and industrial ecosystems and technology adoption in a new renewable energy ecosystem.

\begin{tabular}{|c|c|c|c|c|}
\hline \multirow[b]{2}{*}{ Research Dimensions } & \multicolumn{3}{|c|}{ Key Themes in Past Research } & \multirow[b]{2}{*}{ Contributions of This Paper } \\
\hline & $\begin{array}{l}\text { Sustainable Consumption and } \\
\text { Production (SCP) }\end{array}$ & $\begin{array}{l}\text { Natural and Industrial } \\
\text { Ecosystems/Complex } \\
\text { Adaptive Systems }\end{array}$ & $\begin{array}{c}\text { Adoption of Renewable } \\
\text { Energy/Bioenergy Technologies }\end{array}$ & \\
\hline Type of sustainability & $\begin{array}{l}\text { Environmental sustainability- } \\
\text { (i.e., minimizing specific types of } \\
\text { environmental impact such as } \\
\text { green-house gas emissions) }\end{array}$ & $\begin{array}{l}\text { Ecosystem's resistance and resilience } \\
\text { to changeSocio-economic viability of } \\
\text { industrial ecosystems }\end{array}$ & $\begin{array}{l}\text { Reduction of impact on } \\
\text { environment \& resistance } \\
\text { and resilience of the industrial } \\
\text { ecosystem to change }\end{array}$ & $\begin{array}{l}\text { Includes both minimizing impact on } \\
\text { environment and increasing } \\
\text { socio-economic viability leading to } \\
\text { industrial ecosystem's resistance and } \\
\text { resilience to change }\end{array}$ \\
\hline Sustainability promoted by: & $\begin{array}{l}\text { - Embracing green consumption } \\
\text { and production; } \\
\text { - Innovation to reduce waste and } \\
\text { upcycle outputs and waste; } \\
\text { - Reducing consumption; } \\
\text { - Reducing environmental harm. }\end{array}$ & $\begin{array}{l}\text { - Species diversity in the ecosystem; } \\
\text { - Presence of interactions and } \\
\text { linkages to promote resource and } \\
\text { knowledge exchange; } \\
\text { - Innovation and niche creation; } \\
\text { - Productivity. }\end{array}$ & $\begin{array}{l}\text { - Adoption of renewable } \\
\text { technologies promoting SCP; } \\
\text { - Adoption of new models of } \\
\text { livelihood generation to } \\
\text { alleviate poverty. }\end{array}$ & $\begin{array}{l}\text { Minimizing environmental impact } \\
\text { \& SCP in biogas ecosystem by: } \\
\text { - Including simple rules to facilitate } \\
\text { adoption of SCP and } \\
\text { environmental sustainability; } \\
\text { - Introducing new players to } \\
\text { improve adoption; } \\
\text { - Building linkages between } \\
\text { adopting and } \\
\text { external communities; } \\
\text { - Creating market niches to improve } \\
\text { economic viability. }\end{array}$ \\
\hline Includes implications for: & $\begin{array}{l}\text { Firms, national governments \& policy, } \\
\text { individual behavior }\end{array}$ & $\begin{array}{l}\text { Various organizations in the } \\
\text { industrial ecosystem }\end{array}$ & $\begin{array}{l}\text { National governments; } \\
\text { organizations; firms, consumers }\end{array}$ & $\begin{array}{l}\text { Entire industrial ecosystem: } \\
\text { National governments; } \\
\text { for-profit \& not-for-profit } \\
\text { organizations, community }\end{array}$ \\
\hline
\end{tabular}




\section{Methods and Findings}

\subsection{Methods}

This paper uses case study methodology to examine the research question regarding how consumption and production models can be embedded in an industrial ecosystem for renewable energy technologies such as biogas to promote adoption, environmental sustainability and economic viability.

Case study methodology is appropriate when asking how or why questions and when the phenomenon is contemporary, rare, unique or critical for theory creation and when relevant behaviors cannot be manipulated [79]. It is advantageous as it deals with a full variety of evidence-documents, artifacts, interviews, and observations [79]. It is also used to extend existing theory to develop new theory [80]. To do so, the paper links literature on sustainable consumption and production with research on natural and industrial ecosystems and technology adoption. Inductive case analysis is used to provide rich context and helps to understand how sustainable consumption and production can be designed into a renewable energy ecosystem and how these promote adoption. Finally, the methodology reveals underlying processes by making concepts concrete [81].

The design of the study was informed by prior literature on renewable energy adoption. Cases were selected for their relevance to the key theme of the author's Fulbright research study conducted in India during 2013-2014 on the commercialization and adoption of renewable energy technologies by bottom-of-the-pyramid populations. They were also selected based on recommendations of key government officials in the Ministry of New and Renewable Energy, New Delhi, and interviews with expert researchers at two leading science and technology institutes where the author was based during the Fulbright study. Biogas related technologies were prominent for decentralized applications in villages and locations where grid connectivity was poor. The paper also draws from a larger on-going study from 2009-2011 of organizations focused on commercialization processes for emerging "green technologies" in India including renewable energy technologies such as energy from biomass, solar and wind. Cases were selected to maximize variation and build into the research design a comparison of different settings to provide more complete insight as recommended [79,82]: a case in a rural setting with small-scale biogas plants using cow manure is presented along with one of a large-scale biogas plant on a poultry and dairy farm outside a major city and one of a start-up in an urban setting using various types of biodegradable waste at both large and small scales. The research was informed by interviews of organization heads and key executives. To ensure reliability, a semi-structured questionnaire was used with many questions to probe different aspects of biogas adoption [83]. To ensure validity, information from cases was triangulated through site visits, presentations, annual reports and other published material. Other interviews that informed the research and helped to triangulate findings include interviews in public organizations such as government ministries and top-ranking science and technology universities with leading government officials, scientists and university researchers [79]. Additionally, the author interviewed CEOs of firms and non-governmental organizations (NGOs) serving bottom-of-the-pyramid (BOP) consumers in the renewable energy sector [79]. The data were also triangulated by attending industry conferences in India on renewable energy technologies. Finally, the author examined published reports of renewable energy adoption in India and other emerging economies to ensure generalizability $[3,4,22-24,27,43,46]$.

Interviews were recorded and transcribed, and the data were analyzed by using categorization and pattern-matching techniques in an iterative process as field data were compared with theory as recommended by Yin [79], Miles and Huberman [84], Eisenhardt [85] and Glaser and Strauss [82]. The analysis began with an examination of the data in the light of the literature on adoption of renewable energy technologies. Categories such as "need for complements", "affordability" "livelihood generation" began to emerge and became sharper as interviews progressed. The understanding that the entire socio-economic structure would need adaptation led to an exploration of the literature on natural and industrial ecosystems, sustainability and sustainable consumption and production. Moreover, the understanding that facilitating adoption by BOP populations required a focus on the means to generate 
a livelihood so that the benefits of a clean environment and clean energy for cooking and lighting could be realized, which led to the insight that new systems could be designed from the start to address such challenges. Thus, iteration from theory to data and vice versa enabled patterns obtained from the data to be matched with the theories discussed in this paper as recommended $[79,82,84,85]$. For example, the importance of diversity for maintaining stability in natural ecosystem theory led to the insight that the entry of social and other entrepreneurs increased the diversity of organizational types available and contributed to the formation of an industrial ecosystem for biogas. The conceptual model presented in Section 2.4 is applied to the cases and insights from these cases are presented in the next section.

\subsection{Insights from Bioenergy Ecosystems in India}

Background. Decentralized renewable energy solutions such as biogas are in consonance with SCP. Although efforts had been made from the 1980s to promote biogas for villages in India, biogas generation was generally considered low-technology and small scale. Only in the early 2000s did the potential of biogas become recognized. This was due to new technologies for processing various types of feedstock and the potential of large scale deployment of biogas in applications such as cooking and transportation, which made it more viable. Key themes derived from three case studies are presented below.

\subsubsection{Case 1. RGSS}

A case study of the use of small-scale biogas in a cow shelter in Rajasthan, India, is provided below to show how energy from biogas promotes SCP through the creation of a robust and resilient industrial ecosystem. Rajasthan is a semi-desert area with scanty rainfall of 2-3 inches per year with frequent famines. During famines, livestock are the worst affected due to lack of feed.

Entry of a new player, a social enterprise. Social enterprises such as NGOs focus on solving problems through services and products for people who are underserved by for-profit and public sector organizations. For example, in times of drought and famine, non-governmental organizations (NGOs) play a major role in saving livestock, especially cows, as they are more likely to perish under stressful conditions than sheep, goats or camels. One such NGO, the Rajasthan Gow Seva Sangh (henceforth RGSS), rescued cows from various places in Rajasthan and fed them during the famine by collecting donations. As cows were adopted and became part of the NGO, they were improved over time by feeding and breeding so that following generations would have higher milk yields. In 2014, RGSS had 280 cows, each producing an average of 10-12 kg of milk per day though some breeds produced up to $30-40 \mathrm{~kg}$ per day.

Adoption of simple rules. To achieve the objective of self-sufficiency and eliminate donations to feed the cows, RGSS adopted rules such as "creating value from waste". The organization also undertook activities to produce products from cow-milk such as butter, cream, ghee (clarified butter) and curds, while pesticides, insecticides, fertilizer and traditional medicines were derived from cow urine with the objective of commercializing these products. Manure was used for biogas and the remaining slurry turned into high quality fertilizer. Biogas was compressed and used to fuel vehicles. At the time of the study (2014), RGSS was selling fertilizer from cow manure worth INR 2,000,000 (USD 29,998.5) per year and pesticides and insecticides worth INR 200,000-300,000 (USD 3000-4500) per year (INR 66.67 = USD 1.00 (2 August, 2016)). Similarly, the rule "use local resources and knowledge" was adopted as products and services based on traditional knowledge systems such as Naturopathy and Ayurveda were offered on the premises of RGSS.

Discovery of market niches. RGSS also experimented with a number of entrepreneurial ventures to discover market niches that would make the organizational economically viable. Besides dairy products, a pharmacological unit was established under the guidance of experts as well as a hospital for naturopathic treatment of various diseases including stomach ailments, diabetes, arthritis, obesity and skin diseases. The pharmacological unit produced about 65 types of medicines based on Ayurveda, the traditional system of medicine, and sold INR 2,400,000-2,500,000 (USD 35,998-37,498) worth of medicines per annum. Lodging was provided for patients on the premises. Additionally, a plant 
nursery had been developed and Rs. 300,000-400,000 (USD 4500-6000) worth of plants were sold annually. A sister institution had also been established for collecting and pasteurizing milk and sold about 3000 L of milk per day with a turnover of INR 900,000,000 (USD 13.5 million) per annum. Lastly, animal feed was also produced for the farming community.

Multiplying interactions and building linkages. RGSS forged linkages with leading institutions to obtain know-how for biogas production. Much of the energy needs of the organization were met through the production of biogas from manure. The technology was developed by a leading Indian technical institute, IIT-Delhi, and installed in RGSS as a demonstration project. According to the head of RGSS, 3-4 cows producing a total of about $40 \mathrm{~kg}$ of dung per day was sufficient for a small plant. RGSS used a basic process to produce biogas on the premises and compressed it into portable cylinders, which were used to run vehicles such as three wheelers. The cost of commercial LPG in 2013 was INR 70 (USD 1.047) per kilogram so purifying biogas as a replacement for LPG (liquified petroleum gas) and bottling it into CNG (compressed natural gas) was economically viable because it provided more revenue than electricity generation for which the government price was only INR 3.19 (USD 0.048). Besides its application in transportation, CNG could be used as a replacement for LPG by commercial establishments for cooking. About $20 \%-30 \%$ of the manure was converted into gas and the process of biogas production enriched the slurry or by-product so that the remaining $70 \%$ resulted in high quality manure. The by-product could also be turned into vermi-compost. External linkages had been built with an academic community, IIT-Delhi, in the process of sourcing the technology and setting up the demonstration project.

RGSS also built linkages with village farmers by providing know-how and training. Additionally, RGSS also helped install about 100 small biogas units near farmers' homes and provided training on how to run the biogas units. The slurry formed excellent manure while the biogas provided cooking fuel; however, new cooking stoves were required to use the biogas. By installing small biogas units, farmers were able to generate fuel for cooking, which was much cleaner than earlier methods. Women benefited greatly as there was less pollution in the kitchen from burning wood or other biomass. A village woman noted in an interview that she was delighted with her new cooking stove and kitchen. It was clean and it took much less time to cook on the new biogas powered stove. Farmers also earned good incomes from selling milk through RGSS's commercial operations and were able to further improve their land and cultivate various crops including vegetables by using solar powered pumps for irrigation. Biogas technology diffused as other farmers adopted it based on their observation of neighboring farmers.

The decentralized biogas systems enabled the formation of a sustainable industrial ecosystem as solutions were local and reduced the need for external energy. Nothing was wasted, and all by-products were re-formulated into value-adding products. Moreover, instead of cutting trees for firewood, villagers used biogas for cooking.

In summary, this case demonstrates that the entry of RGSS helped create a sustainable industrial ecosystem for biogas. Simple rules were followed to develop an ecosystem that embodied SCP with multiple players in the system. RGSS used local resources and promoted their use with farmers, thus creating a production cycle in which all by-products from each stage of production, including waste such as cow dung and cow urine, were turned into valuable products. The adoption of small-scale biogas plants allowed RGSS to produce compressed natural gas (CNG) for transportation and fertilizer while farmers became more self-sufficient in cooking fuel and fertilizer and improved their economic condition. Energy production was local, even though its use was limited to fuel for cooking and transportation. A variety of entrepreneurial ventures helped to discover new market niches. The use of fertilizers and pesticides from natural sources was beneficial as it promoted healthier soil and crops in farms and facilitated farming organically. Moreover, locally available traditional knowledge was used to produce medicines based on Ayurveda, a traditional system of medicine in India, which were much cheaper than allopathic medicines. Additionally, RGSS's interactions with external players like IIT-Delhi facilitated access to new knowledge, while RGSS's interactions with villagers enabled them to turn waste into valuable products and become suppliers of milk for RGSS's commercial milk production unit. While increased consumption has been observed when resources are more freely available, this is not a major issue given 
the low levels of consumption of rural farmers and villagers at the outset. Direct positive experience of using resources available at hand and achieving higher levels of productivity and self-reliance provide sufficient motivation to facilitate wider adoption of these technologies.

\subsubsection{Case 2. AgriWaste}

Entry of a new player. The economic viability of biogas was also demonstrated by an entrepreneur whose company, AgriWaste, installed a biogas plant in 2011 at a cost of INR 20.5 million (USD 306,703) in the outskirts of Bangalore on a poultry and dairy farm with 200,000 poultry birds and 100 cows. The name of the company has been disguised for confidentiality.

Adoption of simple rules. As in the first case, industrial ecosystem creation was based on the adoption of simple rules such as using locally available resources such as cow manure and poultry waste; the slurry was used on the farm or sold. Additionally, the entrepreneur focused on "creating value from waste". A total of 200-250 kg of methane produced from 20 tons of cow waste and poultry waste was compressed into CNG, which was used for cooking, to power electric generators, and to heat the poultry farm for chicks less than a week old. Finally, high quality manure was produced from the slurry. Of the total energy produced, 25 percent was used on the premises and 75 percent was for sale.

Discovery of market niches. The entrepreneur noted that the project was economically viable from the outset as there was sufficient demand for CNG for cooking (as a replacement for LPG) and for powering generators. Supplying CNG for cooking provided more revenue than as a replacement for diesel or petrol. The success of the project led him to scale up to producing $500 \mathrm{~kg}$ of CNG/day. He also aspired to become the largest producer in Asia and was investigating the possibility of turning food waste into energy in Bangalore. However, large-scale production was impeded by the large requirement of manure and poultry litter.

Multiplying interactions and building linkages. The presence of external linkages and interactions is indicated by the fact that the entrepreneur sourced the technology from a biogas system manufacturer in Ahmedabad, Gujarat. Additionally, he developed linkages with the Ministry of New and Renewable Technology which provided funding in the amount of INR 7,300,000 (USD 109,495). He was also aware of the availability of government funding for new projects to solve problems such as waste disposal and electricity shortages. He kept abreast of technology available in India, had imported technology from U.K. and was considering importing German technology for biogas production from food waste as India did not manufacture machines that could segregate waste. Besides successfully tapping into demand for CNG, he used existing channels to create an industrial ecosystem for biogas.

\subsubsection{Case 3. HitechPower}

Entry of a new player. HitechPower, a Bangalore-based start-up (name disguised for confidentiality) founded by a young graduate of Indian Institute of Management, Bangalore developed a dry anaerobic digestion system for digesting bio-waste to produce clean bio-CNG from any kind of biodegradable waste including food waste, municipal solid waste, poultry litter and cow dung. The company used its own engineering team to design shredders to process the bio-waste, and outsourced fabrication. The system was modular and consisted of input shredders, gas storage and sludge de-watering systems and gas piping to the kitchen along with burners to provide a turnkey solution. Further, a remote monitoring system tracked the health of the anaerobic reactor and data were transmitted to the company's servers and analyzed by the operations team to locate and solve problems. The system could process INR 40,000,000 (USD 598,467) worth of gas per day or the equivalent of $70 \mathrm{~kg} /$ day of LPG. The payback period for the system was estimated at two years without subsidies.

Adoption of simple rules. As in the cases outlined above, the entrepreneur used rules such as "use local resources". The technology and system were designed by the company and depended on locally available waste from various types of biomass. As in previous cases, the rule of "creating value from waste" was embedded in the company's mission as biogas from waste was used for cooking and other purposes. 
Discovery of market niches. The entrepreneur explained that the system was not economically attractive at processing capacity levels below $300 \mathrm{~kg}$, and that the company was constantly working to reduce the payback period. Applications were marketed based on where large quantities of bio-waste were to be found and by 2014, the company had 10 systems in operation. These systems had been installed to process bio-waste at a foundation providing food to underprivileged children, in multinational companies, a hotel, and some universities.

Multiplying interactions and building linkages. As in the two cases above, this start-up had to develop an industrial ecosystem for its technology; this included developing linkages and interactions with various organizations (including the Department of Biotechnology and i2 India, a venture capital firm) for funding, potential customers, and technology experts. Ecosystem creation also involved continued interactions with stakeholders facilitated by the technology platform, which allowed for remote monitoring and turnkey management of the system. While stakeholders had to adopt changes to ensure that energy could be effectively produced from waste, the potential for substantial savings resulting from the substitution of CNG for LPG provided a strong incentive to do so.

Table 2 provides a comparison across the three cases of biogas adoption at small and large scales. In all three cases, although the setting and scale of biogas production was different, the elements of a sustainable ecosystem were present. In the case of RGSS, ecosystem sustainability depended on social inclusion of the farmers (as stakeholders) through training and education so that they could share in the benefits of the technology and improve their living conditions and livelihoods. In the other two cases, large scale production meant that securing the availability of biomass for processing and finding the right market niches were crucial. In Agriwaste, the entrepreneur had a large enough number of cattle and poultry to generate sufficient waste; demand for CNG for cooking was lucrative enough to make the project economically viable. Likewise, in HitechPower, the systems required large amounts of bio-waste and in urban areas it was possible to install them only in large companies or a community setting. The savings from using biogas for cooking and simultaneously disposing of waste made the system attractive to large organizations.

Table 2. Comparisons of cases across dimensions of industrial ecosystems design for environmental and socio-economic sustainability.

\begin{tabular}{|c|c|c|c|}
\hline \multirow{2}{*}{ Context } & Case 1-RGSS & Case 2-AgriWaste & Case 3-HitechPower \\
\hline & Rural & Semi-Rural & Urban \\
\hline Biogas feedstock & Cow manure & Cow and poultry manure & $\begin{array}{l}\text { Food waste, municipal solid waste, } \\
\text { cow manure \& poultry litter }\end{array}$ \\
\hline Organization type & Social enterprise & Entrepreneurial start-up & Entrepreneurial start-up \\
\hline Technology & Small scale & Industrial & $\begin{array}{l}\text { Industrial; developed } \\
\text { own technology }\end{array}$ \\
\hline Simple rules created & $\sqrt{ }$ & $\sqrt{ }$ & $\sqrt{ }$ \\
\hline $\begin{array}{l}\text { - Use local resources } \\
\text { - Turn waste into value }\end{array}$ & $\begin{array}{l}\sqrt{ } \\
\sqrt{ }\end{array}$ & $\begin{array}{l}\sqrt{ } \\
\sqrt{ }\end{array}$ & $\begin{array}{l}\sqrt{ } \\
\sqrt{ }\end{array}$ \\
\hline $\begin{array}{l}\text { Discovery of market } \\
\text { niches }\end{array}$ & $\begin{array}{l}\text { RGSS developed multiple } \\
\text { businesses such as fertilizers, } \\
\text { traditional medicine; biogas } \\
\text { locally produced meets } \\
\text { villagers' energy needs } \\
\text { for cooking \& slurry is } \\
\text { used as fertilizer. }\end{array}$ & $\begin{array}{l}\text { Economically viable at outset; } \\
\text { main use is to fill the demand } \\
\text { for compressed natural gas } \\
\text { (CNG) as fuel for cooking and } \\
\text { to power generators. }\end{array}$ & $\begin{array}{l}\text { Large-scale production of bio-CNG } \\
\text { to fill the demand at various urban } \\
\text { sites such as multinational } \\
\text { companies, hotels, universities, etc. }\end{array}$ \\
\hline $\begin{array}{l}\text { Multiplying } \\
\text { interactions \& building } \\
\text { linkages }\end{array}$ & $\begin{array}{l}\text { RGSS drew knowledge } \\
\text { and skills from experts } \\
\text { in technology institutes } \\
\text { like IIT-Delhi. }\end{array}$ & $\begin{array}{l}\text { Obtained technology from } \\
\text { a supplier in another state } \\
\text { in India. }\end{array}$ & $\begin{array}{l}\text { Interacted with the Department of } \\
\text { Biotechnology, a venture capital } \\
\text { firm and technology experts. }\end{array}$ \\
\hline Results & $\begin{array}{l}\text { Biogas adoption in villages } \\
\text { increased productivity, } \\
\text { self-reliance, \& diffused } \\
\text { small scale biogas. }\end{array}$ & $\begin{array}{l}\text { Successful business; } \\
\text { promoted adoption of } \\
\text { CNG as cooking fuel. }\end{array}$ & $\begin{array}{l}\text { Adopted by various organizations } \\
\text { in Bangalore. }\end{array}$ \\
\hline
\end{tabular}




\section{Discussion \& Conclusions}

This paper provides insights on environmental-socio-economic sustainability by suggesting how biogas can be used to sustain livelihoods and reduce environmental impacts of fuel use while being economically viable. Local biogas production for cooking and transportation, power generation and other purposes is important for remote populations as it offers an economically sustainable trajectory for development.

This paper is important for agricultural science because it provides two key insights about how to ensure successful adoption of biogas in a manner that promotes environmental-socio-economic sustainability. First, it emphasizes the need to create an industrial ecosystem and provides a framework to suggest how SCP can be embedded in such an industrial ecosystem to support adoption and realize the benefits of biogas. In contrast, earlier research on technology adoption focused primarily on individual technologies while ignoring the various players comprising an industrial ecosystem.

Second, this paper suggests that it is necessary to consider the mechanisms of value creation and service provision in the industrial ecosystem. Third, it highlights the importance of interactions and linkages both between various participants in the system and externally. Fourth, this paper emphasizes that demand and niche creation are necessary for successful adoption.

Finally, this paper applies the framework to small-scale biogas production for rural India and also to the urban context in Bangalore. As the cases suggest, designing SCP in the industrial ecosystem requires the adoption of simple rules. All three organizations developed interactions and linkages with external organizations and stakeholders. Also, in each of the three cases, the industrial ecosystem depended on waste available locally as input for the production of renewable energy. Additionally, decentralized technologies brought new products and means to generate or supplement livelihoods. Further, the adoption of biogas alleviated pollution at home and in the environment because it recycled waste into new, valuable products such as fertilizer and fuel for cooking and transportation. The success of both Bangalore-based organizations suggests that new technologies such as biogas can be scaled up.

Success achieved at the small-scale/rural level with biogas and the two additional examples of larger/urban bio-energy ecosystems presented in this paper contrast with the failure of a national oil company in India to produce biodiesel from Jatropha Curcas, a new oilseed crop. The long gestation period for Jatropha crops to mature and limited availability of Jatropha seeds $[18,72]$ prevented the establishment of an industrial ecosystem due to an inability to demonstrate sufficient benefit to villagers, scale up production and establish marketing channels to make it economically viable $[18,72]$. In contrast, applications of biogas in the cases presented in this paper were economically viable from the start (for example, with CNG being used as a replacement for LPG), while NGOs like RGSS provided the skills, training and linkages, and demonstrated the value of the biogas by using it for their own needs.

\section{Limitations}

The paper draws on one case of a rural decentralized bio-energy ecosystem that facilitates SCP and resilience and provides two additional cases of larger/urban bio-energy ecosystems that suggest that such industrial ecosystems can be scaled up. Additional large-scale solutions may exist that are not considered here. Moreover, this paper focuses only on biogas; additional industrial ecosystems dimensions may come to light when considering other renewable energy technologies. Nevertheless, support for the framework is indicated by research on grassroots innovations such as community farming and alternative community-based economies such as those found in the UK [46].

In conclusion, this research has implications for theory and practice in developing economies and emerging markets in Asia and Africa where the creation of sustainable, robust and resilient industrial ecosystems is crucial for economic transformation and alleviation of environmental degradation. It also yields insights for industrialized economies in USA and Europe in areas where renewable energy solutions can facilitate forming hyper-local communities that aim to reduce pollution and environmental damage and enhance the health and well-being of citizens. Policy makers could consider 
promoting the development of external linkages that bring knowledge and other resources into the community, enhance entrepreneurial entry, and focus on ensuring the use of local resources when designing industrial ecosystems for environmental and socio-economic sustainability. Future practice can be informed by insights on sustainable production and consumption and resilience in industrial ecosystems for biogas considered in this paper and contribute not only to better economics but also to a better quality of life. Future research could validate the framework by simulating industrial ecosystem sustainability over time and through large sample empirical studies of industrial ecosystems in other locations.

Acknowledgments: The author thanks the United States-India Educational Foundation for field research support in India during 2013-2014 via a Fulbright-Nehru Senior Researcher fellowship. She also thanks the anonymous reviewers from the International Association for the Management of Technology for their comments.

Conflicts of Interest: The author declares no conflict of interest.

\section{References}

1. United Nations. Sustainable Development Goals. 2015. Available online: http://www.un.org/ sustainabledevelopment/sustainable-consumption-production/ (accessed on 30 November 2015).

2. United Nations. Our Common Future-Brundtland Report; Oxford: Oxford University, UK, 2017, in press.

3. Scheftelowitz, M.; Thran, D. Unlocking the Energy Potential of Manure-An Assessment of the Biogas Production Potential at the Farm Level in Germany. Agriculture 2016, 6, 20. [CrossRef]

4. REN21. Renewables 2015 Global Status Report Renewable Energy Policy Network for the 21st Century. 2015. Available online: http://www.ren21.net/status-of-renewables/global-status-report/ (accessed on 30 November 2015).

5. International Energy Outlook. DOE/EIA-0484; U.S. Energy Information Administration: Washington, DC, USA, 2016. Available online: http://www.eia.gov/outlooks/ieo/pdf/0484(2016).pdf (accessed on 15 February 2017).

6. World Bank. 2014. Available online: http://www.worldbank.org/en/country/india/overview (accessed on 30 November 2015).

7. Best, M. Greater Boston's industrial ecosystem: A manufactory of sectors. Technovation 2015, 39, 4-13. [CrossRef]

8. Clarysse, B.; Wright, M.; Bruneel, J.; Mahajan, A. Creating value in ecosystems: Crossing the chasm between knowledge and business ecosystems. Res. Policy 2014, 43, 1164. [CrossRef]

9. Holland, J. Emergence. From Chaos to Order; Basic Books: New York, NY, USA, 1998.

10. Walsh, S.T.; Kirchhoff, B.A.; Newbert, S. Differentiating market strategies for disruptive technologies. IEEE Trans. Eng. Manag. 2002, 49, 341-351. [CrossRef]

11. Tukker, A.; Cohen, M.; de Zoysa, U.; Hertwich, E.; Hofstetter, P.; Inaba, A.; Lorek, S.; Sto, E. The Oslo Declaration on Sustainable Consumption. J. Ind. Ecol. 2006, 10, 9-14. [CrossRef]

12. Pogutz, S.; Micale, V. Sustainable Consumption and Production. Soc. Econ. 2011, 33, 29-50. [CrossRef]

13. Farber, D. Sustainable Consumption, Energy Policy, and Individual Well-Being. Vanderbilt Law Rev. 2012, 65, 1479-1525.

14. Bang, K.K.; Ellinger, A.E.; Hadjimarcou, J.; Traichal, P.A. Consumer Concern, Knowledge, Belief and Attitude toward Renewable Energy: An Application of Reasoned Action Theory. Psychol. Mark. 2000, 17, 449-468. [CrossRef]

15. Pierce, J.C.; Steel, B.S.; Warner, R.L. Knowledge, Culture and Public Support for Renewable Energy Policy. Comp. Technol. Transf. Soc. 2009, 7, 270-286. [CrossRef]

16. Porter, W.E. Renewable Energy in Rural Southeastern Arizona: Decision Factors: A Comparison of the Consumer Profiles of Homeowners Who Purchased Renewable Energy Systems with Those Who Performed Other Home Upgrades or Remodeling Projects. Master's Thesis, Arizona State University, Tempe, AZ, USA, 2011.

17. Prahalad, C. The Fortune at the Bottom of the Pyramid: Eradicating Poverty through Profits; Pearson Educational/Wharton School Publishing: Upper Saddle River, NJ, USA, 2007.

18. Aradhey, A. India Biofuels Annual 2015. In Global Agricultural Information Network; USDA Foreign Agricultural Service: Washington, DC, USA, 2015. 
19. Chanakya, H.; Mahapatra, D.; Madhab, S.; Abitha, R. Algal biofuel production and mitigation potential in India. Mitig. Adapt. Straeg. Glob. Chang. 2013, 18, 113-136. [CrossRef]

20. World Bioenergy Association. WBA Global Bioenergy Statistics. Available online: http://www. indiaenvironmentportal.org.in/files/file/WBA\%20GBS\%202016.pdf. (accessed on 15 February 2017).

21. US Department of Energy. Natural Gas Benefits and Considerations. Alternative Fuels Data Center. Available online: http://www.afdc.energy.gov/fuels/natural_gas_benefits.html (accessed on 15 February 2017).

22. World Bioenergy Association (WBA). WBA Global Bioenergy Statistics 2016. Available online: http://www. worldbioenergy.org/content/wba-global-bioenergy-statistics-2016 (accessed on 15 February 2017).

23. Wachira, C. Africa's First Grid-Connected Biogas Plant to Start in Kenya, Bloomberg, 4 February 2015. Available online: http://www.bloomberg.com/news/articles/2015-02-04/africa-s-first-grid-connectedbiogas-plant-to-start-in-kenya (accessed on 15 February 2017).

24. NDBMP-IDCOL and USTB Beijing. Biogas Audit Bangladesh 2011-2013 Volume II; NDBMP-IDCOL: Dhaka, Bangladesh; USTB: Beijing, China, 2013; Available online: http:/ / webcache.googleusercontent.com/search? q=cache:QExZFnDr1YQJ:www.idcol.org/notice/659c0ce4945cdc12877b94862160c389.pdf $+\& c d=22 \&$ hl= en\&ct=clnk\&gl=us (accessed on 15 February 2017).

25. European Biogas Association. EBA Biomethane \& Biogas Report 2015. Available online: http://europeanbiogas.eu/2015/12/16/biogasreport2015/ (accessed on 15 February 2017).

26. Government of India. India's GHG Emissions Profile. Results of Five Climate Modeling Studies; Climate Modeling Forum; Ministry of Environment and Forest, Government of India: New Delhi, India, 2009.

27. The Energy Research Institute (TERI). Cooking with Cleaner Fuels in INDIA: A Strategic Analysis and Assessment, Policy Brief. Available online: https://www.google.com/search?q=TERI+2010+cooking+with+cleaner+fuels\% 2C\&ie=utf-8\&oe=utf-8\#q=TERI+2010+cooking+with+cleaner+fuels+ (accessed on 1 August 2016).

28. Ministry of Agriculture. 17th Indian Livestock Census - All India Summary Report; Government of India: New Delhi, India, 2003. Available online: http://dahd.nic.in/sites/default/files/17th\%20Indian\%20Livestock\%20Census\% 20All\%20India\%20Summary\%20Report\%20\%201.pdf (accessed on 15 February 2017).

29. Tripathi, A.K. Renewable Energy Statistics; Akshay Urja. Ministry of New and Renewable Energy: New Delhi, India, 2010.

30. Ravindranath, N.; Balachandra, P. Sustainable bioenergy for India: Technical, economic and policy analysis. Energy 2009, 34, 1003-1013. [CrossRef]

31. Nautiyal, S.; Goswami, M.; Manasi, S.; Bez, P.; Bhaskar, K.; Khan, Y. Potential of manure based biogas to replace conventional and non-conventional fuels in India: Environmental assessment for emission reduction. Manag. Environ. Qual. Int. J. 2015, 26, 3-20. [CrossRef]

32. United Nations Environment Programme (UNEP). The Role of Regions/Local Authorities for a Shift towards Green Economy; UNEP: Paris, France, 2011.

33. United Nations Industrial Development Organization. UNIDO Green Industry. Policy for Supporting Green Industry; UNIDO: Vienna, Austria, 2011; p. 84.

34. Staniškis, J. Sustainable consumption and production: How to make it possible. Clean Technol. Environ. Policy 2012, 14, 1015-1022. [CrossRef]

35. Staniškis, J.; Arbačiauskas, V.; Varžinskas, V. Sustainable consumption and production as a system: Experience in Lithuania. Clean Technol. Environ. Policy 2012, 14, 1095-1105. [CrossRef]

36. United Nations Environment Programme (UNEP). Mainstreaming Sustainable Consumption and Production and Resource Efficiency into Development Planning; UNEP: Paris, France, 2009.

37. De Zoysa, U. Millennium consumption goals: A fair proposal from the poor to the rich, (Editorial). Sustain. Sci. Pract. Policy 2011, 7, 1-5.

38. Ehrlich, P.; Holdren, J. Impact of Population Growth. Science 1971, 171, 1212-1217. [CrossRef] [PubMed]

39. Kautto, P. New Instruments-Old Practices? The Implications of Environmental Management Systems and Extended Producer Responsibility for Design for the Environment. Bus. Strategy Environ. 2006, 15, 377-388.

40. Krajnc, D.; Glavič, P. Indicators of sustainable production. Clean Technol. Environ. Policy 2003, 5, $279-288$. [CrossRef]

41. Clark, G. Evolution of the Global Sustainable Consumption and Production Policy and the United National Environmental Programme's (UNEP) Supporting Activities. J. Clean. Prod. 2007, 15, 492-498. [CrossRef]

42. United Nations Environment Programme (UNEP). ABC of SCP, United Nations Environment Program; UNEP: Paris, France, 2010. 
43. Food and Agriculture Organization of the United Nations. Global Forest Resources Assessment 2010; FAO Forestry Paper 163; FAO: Rome, Italy, 2010.

44. World Wildlife Fund. The Living Planet Report, 2014; World Wildlife Fund International: Gland, Switzerland, 2014.

45. Sanne, C. Willing Consumers-Or Locked-in? Policies for Sustainable Consumption. Ecol. Econ. 2002, 42, 273-287.

46. Seyfang, G. The New Economics of Sustainable Consumption: Seeds of Change; Palgrave Macmillan, Houndsmills: Basingstoke, UK, 2009.

47. Daly, H.; Cobb, J. For the Common Good; Greenprint Press: London, UK, 1990.

48. Naess, A. The Deep Ecological Movement. In Deep Ecology for the Twenty-First Century; Sessions, G., Ed.; Shambhala Publications, Inc.: Boston, MA, USA, 1995; pp. 64-84.

49. Narayanan, Y. Sustainable consumption as a means to self-realization: A Hindu perspective on when enough is enough. Sustain. Dev. 2010, 18, 252-259. [CrossRef]

50. Levin, S.A. Fragile Dominion: Complexity and the Commons; Perseus Books: Reading, MA, USA, 1999.

51. Holland, J.; Miller, J. Artificial adaptive agents in economic theory. Am. Econ. Rev. 1991, 81, 365-370.

52. Mitchell, M.; Bennett, E.; Gonzalez, A. Linking Landscape Connectivity and Ecosystem Service Provision: Current Knowledge and Research Gaps. Ecosystems 2013, 16, 894-908. [CrossRef]

53. Chapin, F.S., III; Torn, M.S.; Tateno, M. Principles of Ecosystem Sustainability. Am. Nat. 1996, 6, $1016-1037$. [CrossRef]

54. Palumbi, S.; McLeod, K.; Graünbaum, D. Ecosystems in Action: Lessons from Marine Ecology about Recovery, Resistance, and Reversibility. Bioscience 2014, 58, 33-42. [CrossRef]

55. Holling, C. Resilience and stability of ecological systems. Annu. Rev. Ecol. Syst. 1973, 4, 1-23. [CrossRef]

56. Holling, C. Engineering resilience versus ecological resilience. Eng. Ecol. Constr. 1996, 31, 32.

57. Carpenter, S.; Walker, B.; Anderies, J.; Abel, N. From metaphor to measurement: Resilience of what to what? Ecosystems 2001, 4, 765-781. [CrossRef]

58. Peterson, G.; Allen, C.I.R.; Holling, C.S. Ecological resilience, biodiversity, and scale. Ecosystems 1998, 1, 6-18. [CrossRef]

59. Walker, B. Conserving Biological Diversity through Ecosystem Resilience. Conserv. Biol. 1995, 9, 747-752. [CrossRef]

60. Norberg, J.; Swaney, D.; Dushoff, J.; Lin, J.; Casagrandi, R.; Levin, S. Phenotypic Diversity and Ecosystem Functioning in Changing Environments: A Theoretical Framework. Proc. Natl. Acad. Sci. USA 2001, 98, 11376-11381. [CrossRef] [PubMed]

61. Luck, G.W.; Daily, G.C.; Ehrlich, P.R. Population diversity and ecosystem services. Trends Ecol. Evol. 2003, 18, 331-336. [CrossRef]

62. Olff, H.; Alonso, D.; Berg, M.P.; Eriksson, B.K.; Loreau, M.; Piersma, T.; Rooney, N. Parallel Ecological Networks in Ecosystems. Philos. Trans. R. Soc. B Biol. Sci. 2009, 364, 1755-1779. [CrossRef] [PubMed]

63. Ehrenfeld, J.G. Ecosystem Consequences of Biological Invasions. Annu. Rev. Ecol. Evol. Syst. 2010, 41, 59-80. [CrossRef]

64. Jelinski, L.W.; Graedel, T.E.; Laudise, R.A.; McCall, D.W.; Patel, C.K.N. Industrial Ecology: Concepts and Approaches. Proc. Natl. Acad. Sci. USA 1992, 89, 793-797. [CrossRef] [PubMed]

65. Ruhl, J.B.; Kraft, S.E.; Lant, C.L. The Law and Policy of Ecosystem Services; Island Press: Washington, DC, USA, 2007; pp. 13-35.

66. Holland, J.H. Hidden Order: How Adaptation Builds Complexity; Addison-Wesley: Reading, MA, USA, 1995.

67. Iansiti, M.; Richards, G.L. The information technology ecosystem: Structure, health and performance. Antitrust Bull. 2006, 51, 77-110. [CrossRef]

68. Dale, V.H.; Efroymson, R.A.; Kline, K.L.; Langholtz, M.H.; Leiby, P.N.; Oladosu, G.A.; Davis, M.R.; Downing, M.E.; Hilliard, M.R. Indicators for assessing socioeconomic sustainability of bioenergy systems: A short list of practical measures. Ecol. Indic. 2013, 26, 87-102. [CrossRef]

69. Smith, L.L. Economies and Markets as Complex Systems. Bus. Econ. 2002, 37, 46-53.

70. Muller, A. Sustainable agriculture and the production of biomass for energy use. Clim. Chang. 2009, 94, 319-331. [CrossRef]

71. Hinrichs, C.C.; Welsh, R. The effects of the industrialization of US livestock agriculture on promoting sustainable production. Agric. Hum. Values 2003, 20, 125-141. [CrossRef] 
72. Surie, G. Innovating via emergent technology and distributed organization: A case of biofuels in India. Technol. Forecast. Soc. Chang. 2013, 80, 253-266. [CrossRef]

73. Avagyan, A.B. A contribution to global sustainable development: Inclusion of microalgae and their biomass in production and bio cycles. Clean Technol. Environ. Policy 2008, 10, 313-317. [CrossRef]

74. Brennan, L.; Owende, P. Biofuels from microalgae-A review of technologies for production, processing, and extraction of biofuels and co-products. Renew. Sustain. Energy Rev. 2010, 14, 557-577. [CrossRef]

75. Marques, A.C.; Fuinhas, J.A.; Manso, J.P. A quantile approach to identify factors promoting renewable energy in European countries. Environ. Resour. Econ. 2011, 49, 351-366. [CrossRef]

76. Schot, J. The usefulness of evolutionary models for explaining innovation: The case of the Netherlands in the 19th century. Hist. Technol. 1998, 14, 173-200. [CrossRef]

77. Geels, F.W. From sectoral systems of innovation to sociotechnical systems: Insights about dynamics and change from sociology and institutional theory. Res. Policy 2004, 33, 897-920. [CrossRef]

78. Schot, J.; Hoogma, R.; Elzen, B. Strategies for shifting technological systems: The case of the automobile system. Futures 1994, 26, 1060-1076. [CrossRef]

79. Yin, R.K. Case Study Research: Design and Methods; Sage Publications: Newbury Park, CA, USA, 2003.

80. Lee, W.B. Using Qualitative Methods to Organize Research; Sage Publications: Newbury Park, CA, USA, 1999.

81. Eisenhardt, K.M.; Graebner, M.E. Theory building from cases: Opportunities and challenges. Acad. Manag. J. 2007, 50, 25-32. [CrossRef]

82. Glaser, B.G.; Strauss, A.L. Discovery of Substantive Theory: A Basic Strategy Underlying Qualitative Research. Am. Behav. Sci. 1965, 8, 5-12. [CrossRef]

83. Ragin, C.C. Constructing Social Research; Pine Forge Press: Thousand Oaks, CA, USA, 1994.

84. Miles, M.B.; Huberman, A.M. Qualitative Data Analysis; Sage Publications: Newbury Park, CA, USA, 1994.

85. Eisenhardt, K.M. Building theories from case study research. Acad. Manag. Rev. 1989, 14, 532-550.

(C) 2017 by the author. Licensee MDPI, Basel, Switzerland. This article is an open access article distributed under the terms and conditions of the Creative Commons Attribution (CC BY) license (http:/ / creativecommons.org/licenses/by/4.0/). 